\title{
RESPONSE OF COWPEA TO WATER DEFICIT UNDER SEMI-PORTABLE SPRINKLER IRRIGATION SYSTEM
}

\begin{abstract}
Aboamera, M. A.*
ABSTRACT

Cowpea (Vigna unguiculata, (L.)Walp.) was subjected to water application deficit through a semi-portable sprinkler irrigation system. The experiment was conducted under three levels of water application deficit which were: fully irrigation (with 100\% of soil moisture content at field capacity), $80 \%$, and $60 \%$ of soil moisture content at field capacity. For all levels of water deficit, the highest percentage of water application depth (31.02\%), occurred during mid - season stage. The higher crop evapotranspiration (Etc) value was $\left(6.94 \mathrm{~mm} . \mathrm{d}^{-1}\right)$ observed after 35 days from planting with fully irrigation. At $100 \%$ of soil moisture content at field capacity, the average value of crop coefficient (Kc) was 0.696, 0.615, 0.673 and 0.60 for initial, development, mid - season, and harvesting stage respectively. The average values of water stress coefficient $(K s)$ in development and harvesting stages illustrated that the crop extract from root zone without suffering water stress in the readily available water because of the root zone depletion was smaller than the radial available water in root zone. The highest seed yield (1.12 Mg/feddan) was observed with fully irrigation, while the lowest $(0.67 \mathrm{Mg} / \mathrm{feddan})$ was with $60 \%$ of field capacity. This lowest value of seed yield was associated with low number of pods/plant (14.6 pods /plant) and small increase in number of seeds per pod (11.00 seeds/pod) and average seed weight (20 g/plant). Increasing the deficit percent of water application resulted in progressively lower water use efficiency. At $80 \%$ of field capacity, water use efficiency was $0.68 \mathrm{~kg} / \mathrm{m}^{3}$ while, it decreased to $0.59 \mathrm{~kg} / \mathrm{m}^{3}$ as the deficit percent increased from $80 \%$ to $60 \%$ of soil moisture content at field capacity.
\end{abstract}

Key words: water deficit on cowpea, portable sprinkler irrigation system, actual cowpea evapotranspiration, yield and water use efficiency under deficit irrigation.

*Associate Prof., Agric.Eng.Dept, .Fac. of Agric., Minufiya University 


\section{INTRODUCTION}

ationalization of the irrigation water became a unique and
necessary way to save the water used in the valley of Egypt.
Scheduling the required irrigation water for each crop will help in minimizing the water lost through the growing season.

The effect of water deficit on cowpea growth and yield depend upon the degree of stress and the development stage at which the stress occurs (Hsiao and Acevedo, 1974). The variation of deficit irrigation timing and amount along the growing season of different growth stages might increase yield because it results in a change with dry matter between vegetative and reproduction organs (Ong, 1984).

Sprinkler irrigation systems with low irrigation frequencies of three days increased pod yield of peanut (ranged from 602 to $651 \mathrm{~g} \mathrm{~m}^{-2}$ ) and water use efficiency (WUE) due to decreasing water losses during the irrigation season (Plaut and Ben-Hur, 2005).

The most sensitive growth stages of cowpea to drought were flowering and pod filling, with yield reduction from 35 to $69 \%$ depending on the timing and length of the drought treatment. A soil water deficit during the vegetative stage had the least effect on crop yield. This, coupled with decreased evaporation, resulted in a water-use efficiency which was greater than that of control treatment. The water-use efficiencies of the other stage deficit treatments were decreased below that of the control because of large decrease in crop yield. Seed yield of cowpeas was found to be linearly related to an integrated water stress indicator based on the predawn measurement of leaf water potential. (Shouse, et al., 1981).

Root zone water storage after millet harvest was sufficient to maintain a long duration cowpea cultivar that was able to make use of water that otherwise would have been lost to drainage during dry season (Grema and Hess, 1994).

Vegetative growth was significantly reduced by salt stress during all three stages (vegetative, flowering, and pod filling) but the effect was much less when stress was imposed during the last two stages than during the first stage (Maas and Poss, 1989).

Crop coefficients of cowpea, irrigated by subsurface drip irrigation system were more closely related to days - after - planting (DAP) than to 
growing - degree - days (GDDs). The average value for the crop coefficient during the mid - season plateau was 0.986 for the coefficient used with pan evaporation and it was 1.211 for coefficient used a modified Penman equation for Eto (reference evapotranspiration). For the Penman - Monteith $(\mathrm{P}-\mathrm{M})$ equation, the coefficient was 1.223 (Detar, 2009).

Andrade et al. (1993) found a cowpea crop coefficient for use with Penman reference Et (Kcn) of 1.6 at 42 days - after - planting for a determinate variety.

Souza et al. (2005) in a 69 days season using lysimeters, found the average $(\mathrm{Kcm})=1.27$ at the flowering stage of cowpea. The $(\mathrm{Kcm})$ increased steadily from the beginning up to flowering and peaked at 1.35 on 50 days - after - planting, it then decreased rapidly utile harvest time. Water use of cowpea can be reduced while maintaining seed yields by planned - water - deficit irrigation. Major increases in water use efficiency may be achieved by withholding irrigation from plant emergence to the first appearance of macroscopic floral buds, providing a moderate supply of water is present in the soil profile and no precipitation occurs (Ziska and Hall, 1983).

Abou kherira (2009) showed that, deficit irrigation significantly affected yields, where kernels yield decreased by $28.39,36$, and $41 \%$ in deficit irrigated late vegetative and early flowering, late flowering and early pegging, pegging and pod formation growth stages respectively, compared with full irrigation treatments. Peanut yield response factor (ky), which indicates the relative reduction in yield to relative reduction in crop evapotranspiration (Etc), averaged 2.9with higher than the 0.7 value reported by Doorenbos and Kassam, 1979.

Generic crop coefficient $(\mathrm{Kc})$ values were developed from unknown resources, indicating the climate, cropping season and height of the crop, without considering the cultivar specifications. Rarely an attempt was made to estimate site - and cultivar - specific coefficient $\left(\mathrm{K}_{\mathrm{c}} \mathrm{s}\right)$ under given climate conditions. Local regional calibration of FAO $(\mathrm{Kc})$ curve is strongly recommended for achieving the accuracy of irrigation scheduling and water allocation (Farahani et al., 2008). 
Water deficit imposed during the vegetative stage of peanut achieved greater final yields and increased water use efficiency and dry matter production including economic yield (Nautiyal et al., 2000).

The objective of the present investigation was to study the effect of water stress on the cowpea seed yield under portable sprinkler irrigation system, and to evaluate the actual water consumption at each stage of growing. In addition, to estimate the effect of water deficit on crop coefficient and water use efficiency.

\section{MATERIALS AND METHODS}

\subsection{Experimental site and climate}

Field experiments were conducted during the 2004 at Inshas Experimental Station, Institute of Irrigation Methods and Water Management Researches, National Water Research Center, Egypt. The location sited at a longitude of $31.35^{\circ} \mathrm{E}$, Latitude $30.24^{\circ} \mathrm{N}$ and altitude of $25.5 \mathrm{~m}$. Chemical properties and analysis of the used water in irrigation presented in table (2.1).

Table (2.1): Some chemical properties and analysis of water used in irrigation.

\begin{tabular}{|c|c|c|c|c|c|c|c|c|c|}
\hline \multirow{2}{*}{$\begin{array}{c}\text { Electrical } \\
\text { conductivity } \\
\text { EC } \\
\left(\text { ds. } \mathrm{m}^{-1}\right)\end{array}$} & \multicolumn{4}{|c|}{$\begin{array}{c}\text { Cations } \\
\text { (meq.L }\end{array}$} & \multicolumn{4}{|c|}{$\left.\begin{array}{c}\text { Anions } \\
\text { (meq.L }\end{array}{ }^{-1}\right)$} & \\
\cline { 2 - 10 } & $\mathrm{Ca}^{2+}$ & $\mathrm{Mg}^{2+}$ & $\mathrm{Na}^{+}$ & $\mathrm{K}^{+}$ & $\mathrm{Co}_{3}$ & $\mathrm{H} \mathrm{Co}_{3}^{-}$ & $\mathrm{Cl}^{-}$ & So $_{4}{ }^{2}$ & \\
\hline $\mathbf{0 . 3 8}$ & $\mathbf{1 . 8 0}$ & $\mathbf{0 . 6 7}$ & $\mathbf{1 . 4 4}$ & $\mathbf{0 . 1 5}$ & $\mathbf{0}$ & $\mathbf{3 . 3 7}$ & $\mathbf{0 . 5 6}$ & $\mathbf{0 . 1 3}$ & $\mathbf{0 . 9 9}$ \\
\hline
\end{tabular}

Table (2.2): Some soil physical properties with depth during the growing season.

\begin{tabular}{|c|c|c|c|c|c|}
\hline $\begin{array}{c}\text { Soil } \\
\text { depth } \\
(\mathrm{cm})\end{array}$ & $\begin{array}{c}\text { Soil } \\
\text { bulk } \\
\text { density } \\
(\text { g.cm-3 })\end{array}$ & $\begin{array}{l}\text { Soil moisture } \\
\text { content at field } \\
\text { capacity } \\
\left(\mathbf{m}^{\mathbf{3}} \cdot \mathrm{m}^{-\mathbf{3}}\right)\end{array}$ & $\begin{array}{l}\text { Soil moisture } \\
\text { content at } \\
\text { wilting point } \\
\left(\mathbf{m}^{3} \cdot \mathbf{m}^{-3}\right)\end{array}$ & pH & $\begin{array}{c}\text { Electrical } \\
\text { conductivity, } \\
\text { EC } \\
\left(\mathbf{d s} \cdot \mathbf{m}^{-1}\right)\end{array}$ \\
\hline $0-15$ & 1.40 & 0.150 & 0.075 & 7.50 & 0.15 \\
\hline $15-30$ & 1.52 & 0.145 & 0.073 & 8.20 & 0.15 \\
\hline $30-45$ & 1.51 & 0.120 & 0.060 & 8.10 & 0.82 \\
\hline $45-60$ & 1.54 & 0.115 & 0.058 & 7.70 & 0.75 \\
\hline $60-75$ & 1.53 & 0.105 & 0.053 & 7.40 & 0.67 \\
\hline
\end{tabular}


Soil texture in almost all segments was sandy. The average soil moisture content at field capacity was $0.127 \mathrm{~m}^{3} . \mathrm{m}^{-3}$, while the average soil moisture content at wilting point was $0.064 \mathrm{~m}^{3} \cdot \mathrm{m}^{-3}$. Both of some soil physical properties and chemical analysis were listed in tables ( $2.2 \& 2.3)$ respectively.

Table (2.3: Some soil chemical properties with depth during the growing season.

\begin{tabular}{|c|c|c|c|c|c|c|c|c|c|}
\hline \multirow{2}{*}{ 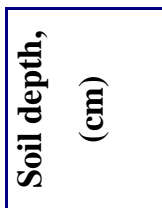 } & \multicolumn{4}{|c|}{$\begin{array}{l}\text { Cations } \\
\left(\text { meq. }^{-1}\right)\end{array}$} & \multicolumn{4}{|c|}{$\begin{array}{c}\text { Anions } \\
\left(\text { meq. } \mathbf{L}^{-1}\right)\end{array}$} & \multirow{2}{*}{ SAR } \\
\hline & $\mathrm{Ca}^{2+}$ & $\mathrm{Mg}^{2+}$ & $\mathrm{Na}^{+}$ & $\mathbf{K}^{+}$ & $\mathrm{Co}_{3}{ }^{-}$ & $\mathrm{HCO}_{3}{ }^{-}$ & $\mathrm{Cl}^{-}$ & $\mathrm{So}_{4}{ }^{2-}$ & \\
\hline $0-15$ & 0.90 & 0.60 & 0.30 & 0.01 & 0 & 1.00 & 0.64 & 0.17 & 0.35 \\
\hline $15-30$ & 0.60 & 0.90 & 0.30 & 0.01 & 0 & 1.10 & 0.64 & 0.07 & 0.35 \\
\hline $30-45$ & 6.60 & 3.00 & 0.30 & 0.03 & 0 & 2.15 & 0.88 & 6.90 & 0.14 \\
\hline $45-60$ & 6.50 & 1.50 & 0.30 & 0.03 & 0 & 4.73 & 0.80 & 2.80 & 0.15 \\
\hline $60-75$ & 5.40 & 1.80 & 0.40 & 0.01 & 0 & 2.15 & 0.96 & 4.50 & 0.21 \\
\hline
\end{tabular}

Weather data including daily maximum, minimum and average temperature, wind speed and average daily reference evapotranspiration pan (Eto) were obtained from an automatic weather station located within $50 \mathrm{~m}$ from the experimental site. These measured data for the interval (April - October) were presented in table (2.4).

\subsection{Experimental semi-portable sprinkler irrigation system}

The used semi-portable sprinkler irrigation system was constructed and tested in the experimental location before sowing cowpea crop. It consisted of a centrifugal pump operated by a diesel engine, main line $\left(\varphi 5^{\prime \prime}\right)$ made of Poly Vinyl Chloride (PVC) was buried at $1 \mathrm{~m}$ depth beneath the soil surface, and aluminum sub main line $\left(\varphi 4^{\prime \prime}\right)$ was connected with also aluminum lateral lines $\left(\varphi 3^{\prime \prime}\right)$.The used sprinkler heads (Rain Bird 30 TNT), with a riser (1m height) for each head, were arranged and fitted on the lateral line and the system operated at an average pressure of $300 \mathrm{kPa}$ with an average discharge of $42.8 \mathrm{~L} \cdot \mathrm{min}^{-1}$ for each sprinkler. The distance between sprinklers was $12 \mathrm{~m}$ and was also $12 \mathrm{~m}$ between laterals. The experimental area was divided into three treatments; each was of $72 \mathrm{~m}$ long and $15 \mathrm{~m}$ width. The area of each treatment was irrigated by a separate lateral line which was connected with five sprinkler heads, 
Table (2.4): Daily maximum, minimum and average temperature, wind speed and average daily reference evapotranspiration (Eto) for the experimental site

\begin{tabular}{|c|c|c|c|c|c|}
\hline Month & 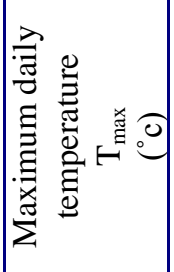 & 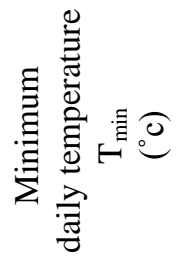 & 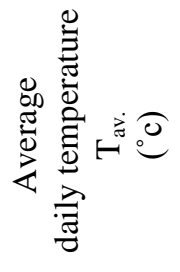 & 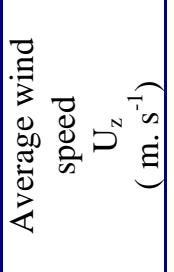 & 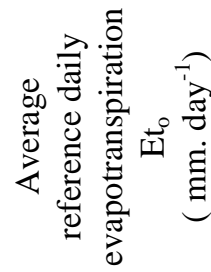 \\
\hline April & 30.10 & 9.60 & 19.85 & 1.35 & 5.04 \\
\hline May & 34.40 & 14.50 & 24.45 & 1.51 & 5.60 \\
\hline June & 35.60 & 16.40 & 26.00 & 1.37 & 6.30 \\
\hline July & 34.90 & 20.10 & 27.50 & 1.29 & 6.10 \\
\hline August & 36.20 & 20.40 & 28.30 & 1.06 & 5.40 \\
\hline September & 31.70 & 20.40 & 26.05 & 0.99 & 4.50 \\
\hline October & 30.00 & 19.50 & 24.75 & 1.10 & 3.50 \\
\hline
\end{tabular}

and the irrigation event was carried out individually for each treatment. Figure (2.1) represents a schematic diagram of the experimental portable sprinkler irrigation system and the location of each treatment. Both of the applied water and the operating pressure were measured by a flow meter and a pressure gauge which were fitted at the main line.

\subsection{Experimental procedure}

Cowpea (Vigna unguiculata, (L.)Walp.) was planted in the experimental field with a rate of $35 \mathrm{~kg} / f$ eddan. The distance between rows was $70 \mathrm{~cm}$ and was $25 \mathrm{~cm}$ between plants. A distance of $1 \mathrm{~m}$ was left between treatments to prevent interference effect from treatments. Each treatment was divided into three experimental plots; each was $25 \times 15 \mathrm{~m}$ and was considered as a replication. All the agricultural processes were carried out as normal for all treatments. In each irrigation event, volume of water application was calculated according to the following equation considering that the irrigation system efficiency (which is prior calculated) is $80 \%$.

$$
\mathbf{I R}=(\mathbf{F} . \mathrm{C}-\mathrm{M} . \mathrm{B}) \times \boldsymbol{\rho} \times \mathbf{Z} \times \mathbf{A} / \boldsymbol{\eta}
$$

Where:

$\mathbf{I R}=$ Volume of water at each irrigation event, $\left(\mathrm{cm}^{3}\right)$

F.C $=$ Soil moisture content at field capacity, $(\%)$

M.B = measured soil moisture content before irrigation, $(\%)$ 
$\boldsymbol{\rho}=$ Soil bulk density $\left(\mathrm{g} / \mathrm{cm}^{3}\right), \mathbf{Z}=$ Depth of root zone $(\mathrm{cm})$, $\mathbf{A}=$ Irrigated are $\left(\mathrm{cm}^{2}\right)$, and $\boldsymbol{\eta}=$ Irrigation system efficiency $(\eta=0.80)$

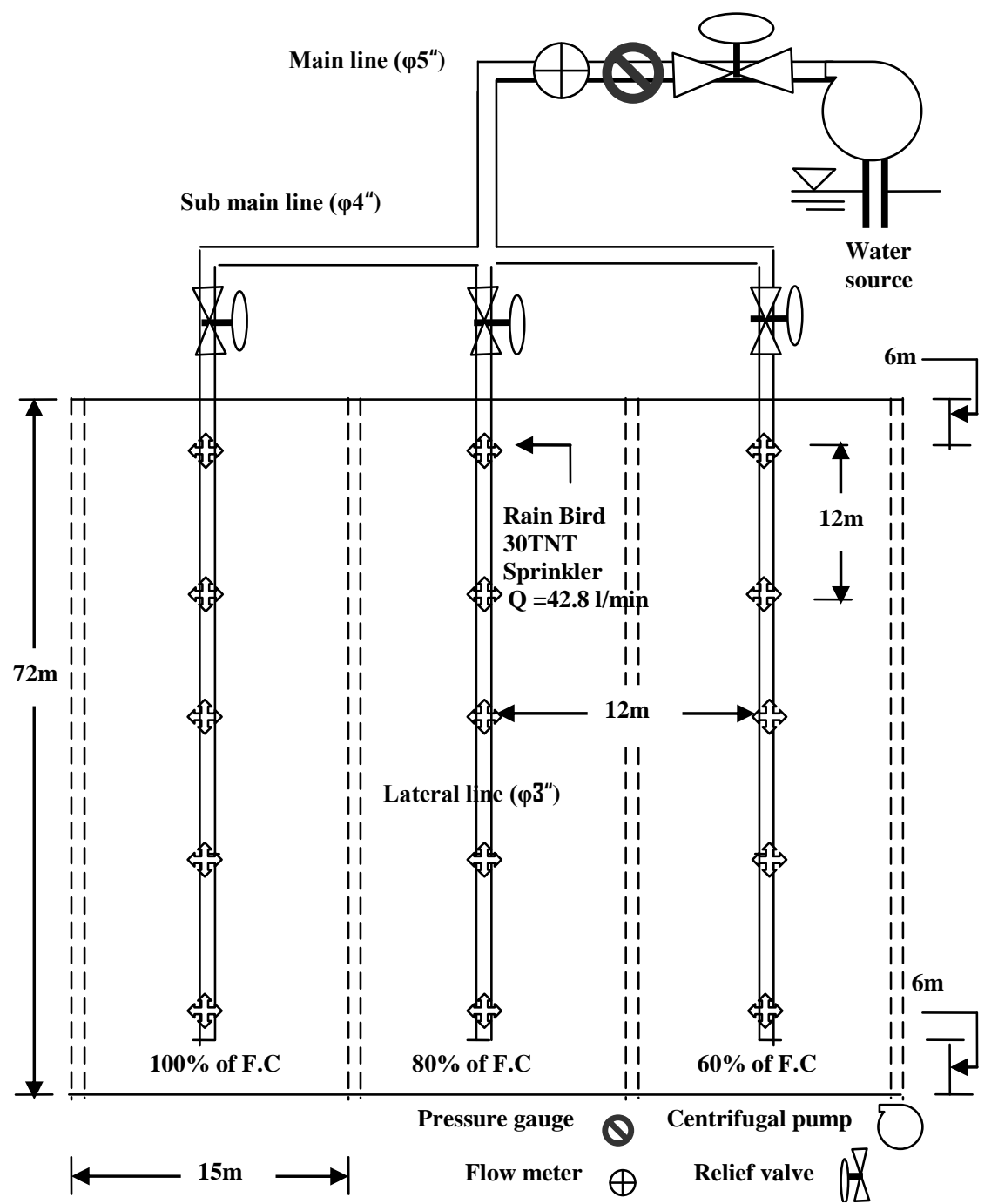

Fig. (2.1): Schematic diagram of the experimental semi-portable sprinkler irrigation system

The three tested treatments were characterized according to the level of the soil moisture content before irrigation (M.B) as related to soil moisture content at field capacity (F.C), where the three treatments are:

(1) Fully irrigation (M.B $=100 \%$ of soil moisture content at field capacity, F.C,)

(2) (M.B $=80 \%$ of soil moisture content at field capacity, F.C,), and 
(3) (M.B $=60 \%$ of soil moisture content at field capacity, F.C,)

\subsection{Measurements of crop evapotranspiration (Etc)}

Actual crop evapotranspiration of cowpea (Etc) in $\left(\mathrm{mm} \cdot \mathrm{d}^{-1}\right)$ was estimated using the following equation (Jensen, 1973):

$$
\text { Etc }=\left[(I R+P-D)+\sum_{i=1}^{i=n}\left\{\left(\theta_{1}-\theta_{2}\right) \cdot \Delta S_{i}\right\}\right] / \Delta t-\cdots-(2.2)
$$

Where:

IR, $\mathbf{P}$, and $\mathbf{D}=$ irrigation, precipitation, and deep percolation from the bottom of root zone $(\mathrm{mm})$,

$\mathbf{n}=$ number of soil layers,

$\boldsymbol{\Delta} \mathbf{S}=$ the thickness of each soil layer $(\mathrm{mm})$,

$\boldsymbol{\theta}_{1} \& \boldsymbol{\theta}_{2}=$ the volumetric soil water content $\left(\mathrm{cm}^{-3} \cdot \mathrm{cm}^{-3}\right)$ at $24 \mathrm{~h}$ after irrigation and $30 \mathrm{~h}$ before the next irrigation, and $\Delta t=$ the time interval between two consecutive measurements (day).

\subsection{Estimation of Cowpea crop coefficient (Kc)}

The value of cowpea crop coefficient in each growing stage was calculated from the estimated crop evapotranspiration $\left(\mathrm{Et}_{\mathrm{c}}\right)$ of the cowpea under non - stressed condition and the reference evapotranspiration pan $\left(\mathrm{Et}_{\mathrm{o}}\right)$ which listed in table (2.4). The average Eto was calculated from pan evaporation class A with factor of 0.7 which given by Doorenbos and Kassam, 1979. The value of cowpea crop coefficient $\left(K_{c}\right)$ at each growing stage was calculated as follows:

$$
\mathbf{K}_{\mathbf{c}}=\mathbf{E t}_{\mathbf{c}} / \mathbf{E t}_{\mathbf{o}}
$$

The general crop coefficient described by the above equation includes the effects of evaporation from both plant and soil surfaces.

Richard et al (2000) stated that, when the potential energy of the soil water drops below a threshold value, the crop is said to be water stressed. The effects of soil water stress are described by multiplying the basal crop coefficient by the water stress coefficient (Ks) as follows:

$$
\mathbf{E t}_{\mathbf{c a d j}}=(\mathbf{K s ~ K c b}+\mathbf{K e}) \mathbf{E t}_{\mathbf{o}}
$$

For soil water limiting conditions, Ks $<1$.Where there is no water stress, $\mathrm{Ks}=1$.

Ks described the effect of water stress on crop transpiration. Where the single crop coefficient is used, the effect of water stress is incorporated into $\mathrm{Kc}$ as follows: 


$$
\mathbf{E t}_{\mathrm{cadj}}=\mathrm{Ks} \mathrm{Kc} \mathrm{Et_{ \textrm {o } }}
$$

Where:

$\mathbf{E t}_{\text {cadj }}=$ crop evapotranspiration under non- standard conditions (mm. $\left.\mathrm{d}^{-1}\right)$

$\mathbf{E t}_{\mathbf{0}}=$ reference crop evapotranspiration $\left(\mathrm{mm} . \mathrm{d}^{-1}\right)$

$\mathbf{K c b}=$ basal crop coefficient.

$\mathbf{K e}=$ soil evaporation coefficient.

$\mathbf{K c}=$ crop coefficient.

$\mathbf{K s}=$ water stress coefficient

The total available water in the root zone is the difference between the water content at field capacity and wilting point and can be calculated according to the following equation:

$$
\mathrm{TAW}=1000\left(\theta_{\mathrm{FC}}-\theta_{\mathrm{WP}}\right) \mathrm{Zr}
$$

Where:

TAW = total available water in the root zone $(\mathrm{mm})$,

$\boldsymbol{\theta}_{\mathbf{F C}}=$ water content at field capacity $\left(\mathrm{cm}^{-3} \cdot \mathrm{cm}^{-3}\right)$

$\boldsymbol{\theta}_{\mathbf{W P}}=$ water content at wilting point $\left(\mathrm{cm}^{-3} \cdot \mathrm{cm}^{-3}\right)$, and $\quad \mathbf{Z r}=$ rooting depth (m).

The value of Ks can be determined according to the following equation:

$$
\text { Ks }=(\text { TAW }- \text { Dr }) /(1-\beta) \text { TAW }
$$

Where:

$\mathbf{K s}=$ dimensionless transpiration reduction factor dependent on available soil water,

Dr $=$ root depth depletion $(\mathrm{mm})$

$\boldsymbol{\beta}=$ fraction of TAW that a crop extract from root zone without suffering water stress. Often, a constant value is used for $\boldsymbol{\beta}$ for a specific growing period ( $\boldsymbol{\beta}=0.45$ for cowpea) as mentioned by Richard et al (2000).

\subsection{Estimation of $(\mathrm{Ks})$}

The estimation of $\mathbf{K s}$ requires a daily water balance computation for the root zone. The root zone can be presented by means of a container in which the water content may fluctuate. To express the water content as root zone depletion is useful. It makes the adding and subtracting of losses and gains straightforward as the various parameters of the soil water budget are usually expressed in terms of water depth. Rainfall, irrigation and capillary rise of groundwater towards the root zone add water to the root zone and decrease the root zone depletion. Soil 
evaporation, crop transpiration and percolation losses remove water from the root zone and increase the depletion. The daily water balance, expressed in terms of depletion at the end of the day is calculated as mentioned by Richard et al (2000):

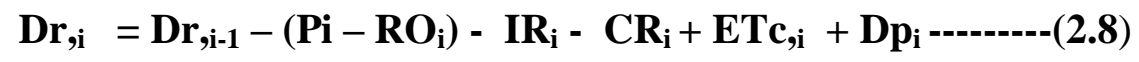

Where:

Dr $_{, \mathbf{i}}=$ root zone depletion at the end of day i $[\mathrm{mm}]$,

Dr, ${ }_{\mathbf{i}-1}=$ water content in the root zone at the end of the previous day, $\mathrm{i}-1$ [mm],

$\mathbf{P i}=$ precipitation on day i $[\mathrm{mm}],\left(\mathbf{P i} \& \mathbf{R} \mathbf{O}_{\mathbf{i}}=\mathbf{0}\right)$

$\mathbf{R O}_{\mathbf{i}}=$ runoff from the soil surface on day $\mathrm{i}[\mathrm{mm}]$,

$\mathbf{I} \mathbf{R}_{\mathbf{i}}=$ net irrigation depth on day $\mathrm{i}$ that infiltrates the soil [mm],

$\mathbf{C R}_{\mathbf{i}}=$ capillary rise from the groundwater table on day i $[\mathrm{mm}],\left(\mathbf{C R}_{\mathbf{i}}=\mathbf{0}\right)$

$\mathbf{E T c}_{\mathbf{i}_{\mathbf{i}}}=$ crop evapotranspiration on day i $[\mathrm{mm}]$,

$\mathbf{D} \mathbf{p}_{\mathbf{i}}=$ water loss out of the root zone by deep percolation on day i [mm $\left(\mathbf{D} \mathbf{p}_{\mathrm{i}}=\mathbf{0}\right)$.

\section{RESULTS AND DISCUSSION}

\subsection{Water application depth}

The growing season for cowpea was divided into four stages, initial, development, mid - season and harvesting. Table (3.1) represents water application depth in $(\mathrm{mm})$ for cowpea during each growing stage and the total water depth for each treatment. The presented results showed that, for all treatments, the percent of water application depth during initial, development, mid - season and harvesting were $27.50 \%, 23.02 \%, 31.02 \%$ and $18.46 \%$ form the total water application respectively. The highest percentage of water application depth occurred for all treatments during mid - season stage $(31.02 \%)$, where the rate of growing in this stage increases and the plants need a lot of water compared with other stages. Figure (3.1) shows the variation of water application depth along the growing season for the tested rates of water deficits. It illustrates that, water application depth, for all treatments, took the same trend along the growing season, but with lower values according to the percent of water deficit. The figure also showed that, water application depth for each growing stage depends only 
on the climatic condition (which is presented in table 2.4) and the soil status besides the rate of growing of cowpea.

Table (3.1): Depth of water application for the different growing stages along the growing season of cowpea.

\begin{tabular}{|c|c|c|c|}
\hline \multirow{2}{*}{ Days after planting } & \multicolumn{3}{|c|}{ Treatments } \\
\cline { 2 - 4 } & \multicolumn{3}{|c|}{ Water application depth } \\
(days)
\end{tabular}

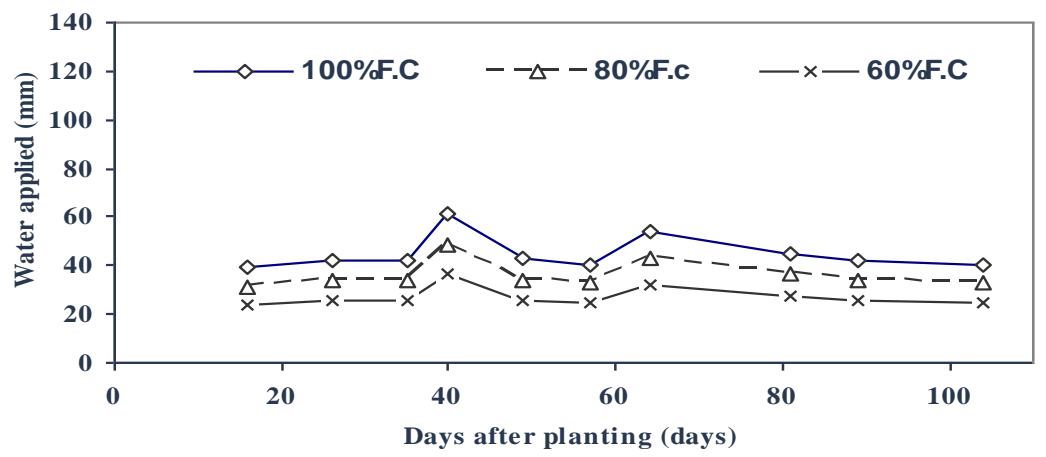

Fig.(3.1):Water application for the three tested treatments along the growing seas on 


\subsection{Irrigation water depth under deficit conditions.}

Figure (3.2) represents the variation of both references (Eto) and irrigation depth along the growing season of cowpea. For all treatments, the higher irrigation depth value $\left(6.94 \mathrm{~mm} . \mathrm{d}^{-1}\right)$ was observed after 35 days from planting with fully irrigation (100\% of F.C). The lowest value of (Etc) was observed with $60 \%$ of soil moisture content at field capacity at harvesting stage. During development and mid - season stages, the value of (Etc) tend to have the same trend at $100 \%$ and $80 \%$ of soil moisture content at field capacity but at $60 \%$, during the mid - season, the value of (Etc) was much lower comparing with $100 \%$ and $80 \%$ of soil moisture content at field capacity of deficit application. The value of (Etc) at mid - season stage was closer to the value of (Eto) with100\% and $80 \%$ of soil moisture content at field capacity of deficit application. While with $60 \%$ of deficit application, it was greatly lower than the value of (Eto) at this stage. This reflexes the effect of application with water deficit on the actual consumption of water by cowpea crop. With fully irrigation (100\% of soil moisture content at filed capacity) and after 35 days from planting, the value of (Etc) was greater than that recorded for the (Eto); this may be due to decreasing the value of soil moisture content before irrigation, which occurred at this level.

At the end of the cowpea growing season with harvesting stage, the three tested levels of water deficit varied according to the level of deficit

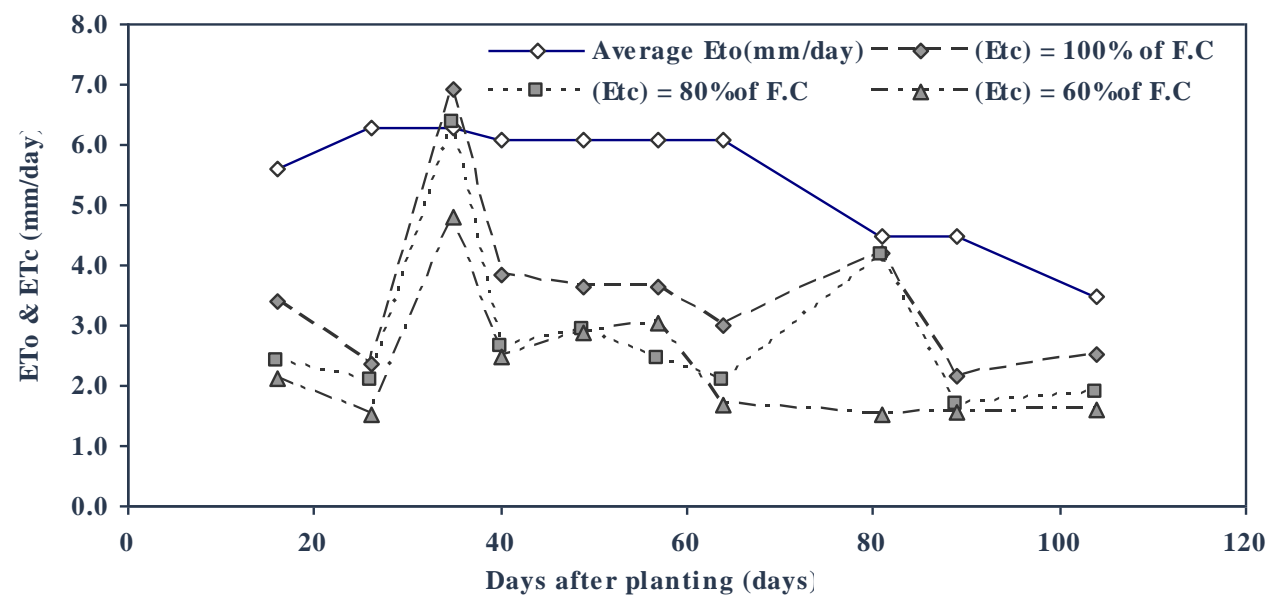

Fig.(3.2 ) Average refernce and crop evapotranspiration along the growing seas 
percent, where the value of (Etc) at harvesting stage decreased as the level of deficit percent increased.

\subsection{Crop coefficient $(\mathbf{K c})$}

Crop coefficient is considered an important parameter for better planning and management of water resources. Its value depends on the growing stages, crop variety and climatic conditions. Changing the value of cowpea crop coefficient, along the growing season, for all treatments, was approximately with similar trend as presented in figure (3.3). But the value of $(\mathrm{Kc})$ at each period, depended upon the decreasing percent of deficit application.

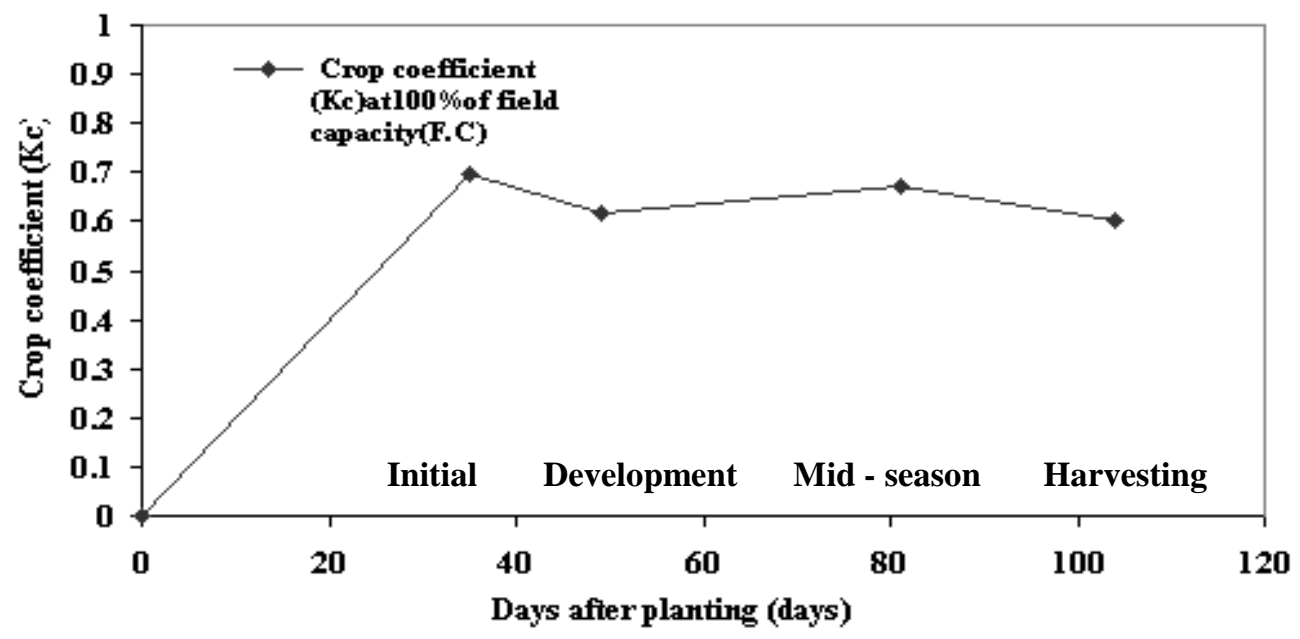

Fig. (3.4): Average value of cowpea crop coefficient (Kc) with the four stages of growing

The presented values of $(\mathrm{Kc})$ in table (3.2) showed that its higher value was occurred at the initial stage for all the three tested levels of water deficit. The average value of $(\mathrm{Kc})$ was $0.696,0.615,0.673$ and 0.60 for initial, development, mid - season, and harvesting stage respectively with full irrigation (100\% of F.C).

\subsection{Water stress coefficient (Ks)}

The total available water (TAW) in the root zone was calculated according to equation (2.6), where the average soil moisture content at field capacity was $0.127 \mathrm{~m}^{3} . \mathrm{m}^{-3}$, and was $0.064 \mathrm{~m}^{3} \cdot \mathrm{m}^{-3}$ at wilting point The value of TAW was $47.25 \mathrm{~mm}$ considering that the total root depth of cowpea is $75 \mathrm{~cm}$. Root depth depletion (Dr) along the growing season 
was calculated using equation (2.8) and by substituting of TAW and Dr in equation (2.7) taking $\boldsymbol{\beta}=0.45$, the value of water stress coefficient (Ks) can be determined. Table (3.3) represents the fluctuation of the water stress coefficient (Ks) along the growing season and the crop evapotranspiration under non- stressed conditions (Etcadj).

Table (3.2): Calculated crop coefficient at $100 \%$ of field capacity and the calculatedvalue of crop evapotranspiration at the three levels of water deficit along the growing season of cowpea

\begin{tabular}{|c|c|c|c|c|c|}
\hline \multirow{3}{*}{$\begin{array}{c}\text { Days after } \\
\text { planting } \\
\text { (days) }\end{array}$} & \multirow{3}{*}{$\begin{array}{l}\text { Average } \\
\text { daily } \\
\text { reference } \\
\text { Eto } \\
\text { mm. d }\end{array}$} & \multirow{3}{*}{$\begin{array}{c}\text { Crop } \\
\text { coefficient } \\
\text { at } \\
100 \% \mathrm{~F} . \mathrm{C} \\
(\mathrm{Kc})\end{array}$} & \multicolumn{3}{|c|}{ Treatments } \\
\hline & & & $100 \%$ F.C & $80 \%$ F.C & $60 \%$ F.C \\
\hline & & & $\begin{array}{c}\text { Etc } \\
\text { mm. } d^{-1}\end{array}$ & $\begin{array}{c}\text { Etc } \\
\text { mm. } d^{-1}\end{array}$ & $\begin{array}{c}\text { Etc } \\
\text { mm. } d^{-1}\end{array}$ \\
\hline 16 & 5.6 & 0.61 & 3.41 & 2.39 & 2.12 \\
\hline 26 & 6.3 & 0.38 & 2.38 & 2.09 & 1.51 \\
\hline 35 & 6.3 & 1.10 & 6.94 & 6.38 & 4.82 \\
\hline Initial & & 0.696* & & & \\
\hline 40 & 6.1 & 0.63 & 3.86 & 2.66 & 2.50 \\
\hline 49 & 6.1 & 0.60 & 3.65 & 2.94 & 2.88 \\
\hline Development & & $0.615^{*}$ & & & \\
\hline 57 & 6.1 & 0.60 & 3.66 & 2.44 & 3.03 \\
\hline 64 & 6.1 & 0.49 & 3.00 & 2.10 & 1.70 \\
\hline 81 & 4.5 & 0.93 & 4.20 & 4.16 & 1.53 \\
\hline Mid - season & & $0.673^{*}$ & & & \\
\hline 89 & 4.5 & 0.48 & 2.15 & 1.67 & 1.57 \\
\hline 104 & 3.5 & 0.72 & 2.51 & 1.87 & 1.60 \\
\hline Harvesting & & $0.600 *$ & & & \\
\hline
\end{tabular}

- =Average value of crop coefficient

The value of readily available water (RAW) which calculated by multiplying total available water (TAW) by $\boldsymbol{\beta}$ is $21.26 \mathrm{~mm}$. When the root zone depletion (Dr) is smaller than $\mathbf{R A W}$, then $\mathbf{K s}=1$. The average values of Ks in development and harvesting stages illustrated that the root zone depletion was smaller than the radial available water in root zone. This means that the crop extract from root zone without suffering water stress in the readily available water during these stages of growing.

\subsection{Adjusted evapotranspiration (Etcadj)}

The effects of soil water stress on crop evapotranspiration (Etc) are described by reducing the value for the crop coefficient as listed in table (3.3). 
Table (3.3) Fluctuation of the water stress coefficient (Ks) along the growing season and the calculated value of crop evapotranspiration under non- standard conditions (Etcadj).

\begin{tabular}{|c|c|c|c|c|c|c|c|c|}
\hline $\begin{array}{c}\text { Days } \\
\text { after } \\
\text { planting } \\
\text { (days) }\end{array}$ & $\begin{array}{c}\text { Eto } \\
\left(\mathbf{m m} \cdot \mathbf{d}^{-1}\right)\end{array}$ & (Kc) & $\begin{array}{c}\text { Etc } \\
\left(\mathbf{m m} \cdot \mathbf{d}^{-1}\right)\end{array}$ & $\begin{array}{c}\text { total } \\
\text { Etc } \\
(\mathbf{m m})\end{array}$ & $\underset{(\mathbf{m m})}{\mathrm{IR}}$ & (Ks) & $\begin{array}{c}\text { Ks } \\
\times \\
\text { Ke }\end{array}$ & $\underset{\left(\mathbf{m m} . \mathbf{d}^{-1}\right)}{\text { Etcadj }}$ \\
\hline 16 & 5.6 & 0.61 & 3.41 & 54.56 & 23.60 & 0.63 & 0.38 & 2.14 \\
\hline 26 & 6.3 & 0.38 & 2.38 & 23.8 & 25.51 & 1 & 0.38 & 2.39 \\
\hline 35 & 6.3 & 1.10 & 6.94 & 62.46 & 25.24 & 0.39 & 0.43 & 2.67 \\
\hline Initial & & $0.696 *$ & & & & $0.673^{*}$ & & \\
\hline 40 & 6.1 & 0.63 & 3.86 & 19.3 & 36.64 & 1 & 0.63 & 3.84 \\
\hline 49 & 6.1 & 0.60 & 3.65 & 32.85 & 25.60 & 1 & 0.60 & 3.66 \\
\hline $\begin{array}{c}\text { Develo } \\
\text { p }\end{array}$ & & $0.615^{*}$ & & & & $1.00 *$ & & \\
\hline 57 & 6.1 & 0.60 & 3.66 & 29.28 & 24.40 & 1 & 0.60 & 3.66 \\
\hline 64 & 6.1 & $\begin{array}{l}0.49 \\
\end{array}$ & 3.00 & 21 & 32.27 & 1 & 0.49 & 2.99 \\
\hline 81 & 4.5 & 0.93 & 4.20 & 71.4 & 27.17 & 0.39 & 0.36 & 1.62 \\
\hline $\begin{array}{l}\text { Mid - } \\
\text { season }\end{array}$ & & $0.673 *$ & & & & $0.797 *$ & & \\
\hline 89 & 4.5 & 0.48 & 2.15 & 17.2 & 25.51 & 1 & 0.48 & 2.16 \\
\hline 104 & 3.5 & 0.72 & 2.51 & 37.65 & 24.40 & 1 & 0.72 & 2.52 \\
\hline $\begin{array}{c}\text { Harves } \\
t\end{array}$ & & $0.600 *$ & & & & $1.00 *$ & & \\
\hline
\end{tabular}

Eto $=$ reference evapotranspiration $\left(\mathrm{mm} \cdot \mathrm{d}^{-1}\right)$

$\mathbf{K c}=$ Crop coefficient at 100\%F.C (-)

Etc $=$ crop evapotranspiration $\left(\mathrm{mm} . \mathrm{d}^{-1}\right)$

$\mathbf{I R}=$ net irrigation depth $(\mathrm{mm})$

Etcadj = evapotranspiration under non - standard conditions $\left(\mathrm{mm} \mathrm{d}^{-1}\right)$ $*$ =Average value of crop coefficient and water stress coefficient.

Figure (3.5) represents the difference between the crop evapotranspiration (Etc) and the adjusted evapotranspiration under non standard conditions (Etcadj) for cowpea along the growing season. The crop evapotranspiration $(\mathrm{Kc})$ fitted with adjusted evapotranspiraion (Etcadj) for all dates along the growing season except after 16\&35 days from planting i.e. during the initial stage of growing, and after 81 days i.e. at the end of mid - season stage. During development and harvest stages, the adjusted evapotranspiration was approximately equal to the 
crop evapotranspiration which means that the crop affected with water stress during initial and mid - season stages.

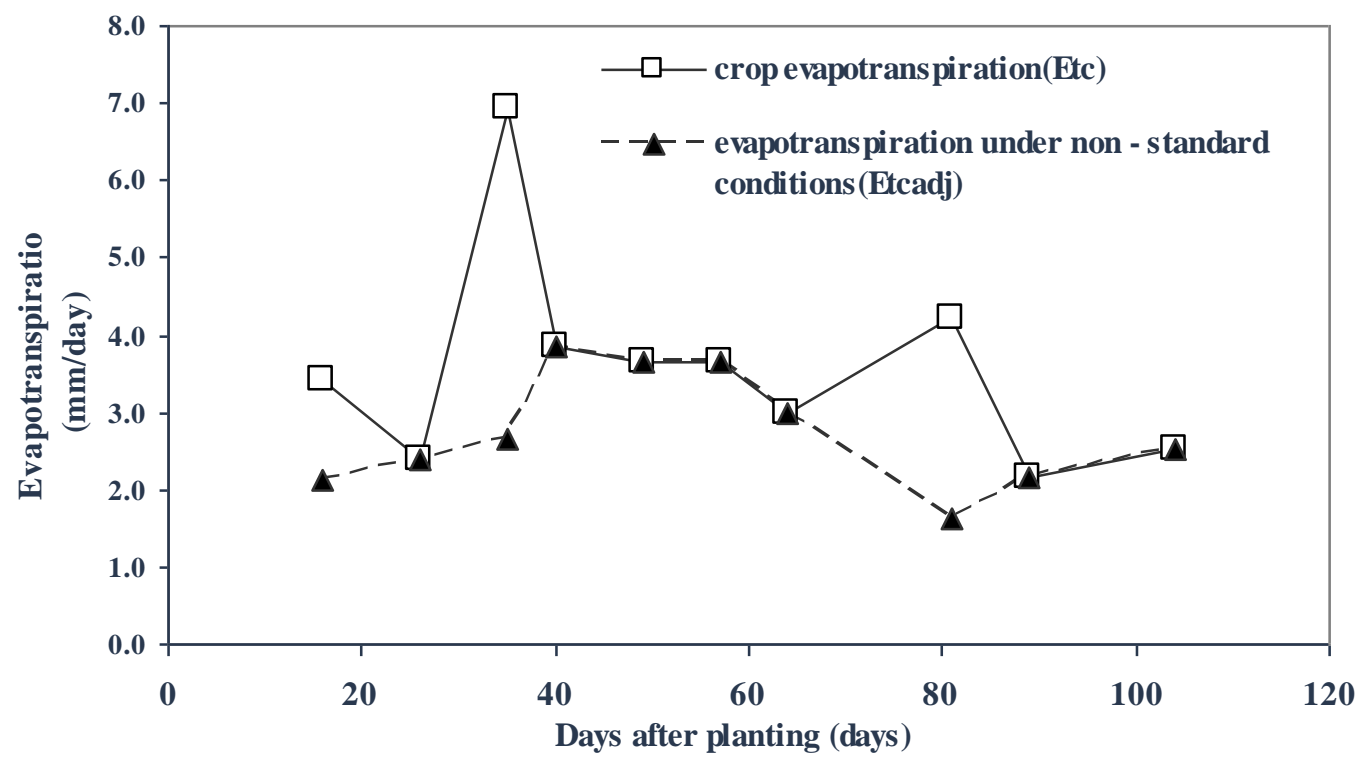

Fig.(3.5 ) :Crop evapotrans piration under non stressed conditions (Etcadj) along the growing seas on of cowpea

It can be concluded that subjected the cowpea to water stress may cause a remarkable difference in crop evapotranspiration. Therefore, the value of crop evapotranspiration might be adjusted, for each stage of growing, to adapt the required water application rate.

\subsection{Yield and water use efficiency}

Table (3.4) represents the cowpea seed yield in (Mg / feddan) and water use efficiency (WUE) in $\mathrm{kg} / \mathrm{m}^{3}$ at the three tested levels of water application deficit. The highest seed yield (1.12 Mg/feddan) was observed with fully irrigation (100\% of soil moisture content at field capacity), while the lowest $(0.67 \mathrm{Mg} /$ feddan $)$ was with $60 \%$ of soil moisture content at field capacity. This lowest value of seed yield was associated with low number of pods/plant (14.6 pods /plant) and small increase in the number of seeds per pod (11.00 seeds/pod) and average seed weight (20.44 g/plant). Generally, the variation in seed yield /feddan was positively correlated with the number of pods per plant. Similar association has been observed in both $80 \%$ and $60 \%$ of soil moisture content at field capacity, where water stress has reduced seed yield. 
Most the reduction in water use efficiency (WUE) resulting from decreasing the total water applied according to the deficit percent and consequently due to the decreasing in seed yield. Increasing the deficit percent of water application resulted in progressively lower water use efficiency. Where, at ( $80 \%$ of soil moisture content at field capacity), water use efficiency was $0.68 \mathrm{~kg} / \mathrm{m}^{3}$ while, it decreased to $0.59 \mathrm{~kg} / \mathrm{m}^{3}$ as the deficit percent increased from $80 \%$ to $60 \%$ of soil moisture content at field capacity.

Table (3.4): Total cowpea seed yield in (Mg / feddan) and water use efficiency for the three tested levels of water deficit.

\begin{tabular}{|c|c|c|c|}
\hline \multirow[b]{3}{*}{ Item } & \multicolumn{3}{|c|}{ Treatments } \\
\hline & \multicolumn{3}{|c|}{ Water application rate } \\
\hline & $\begin{array}{l}100 \% \text { of } \\
\text { field } \\
\text { capacity } \\
\text { (F.C) }\end{array}$ & $\begin{array}{c}80 \% \text { of } \\
\text { field } \\
\text { capacity } \\
\text { (F.C) }\end{array}$ & $\begin{array}{c}60 \% \text { of } \\
\text { field } \\
\text { capacity } \\
\text { (F.C) }\end{array}$ \\
\hline Number of pods /plant & 18.5 & 18.6 & 14.6 \\
\hline Number of seeds/pod & 11.6 & 12.1 & 11.00 \\
\hline Weight of seeds/ pod (g) & 1.80 & 1.60 & 1.40 \\
\hline Weight of seeds/feddan (Mg) & 1.12 & $\mathbf{1 . 0 3}$ & 0.67 \\
\hline Weight of seed / plant (g) & 33.30 & 29.76 & 20.44 \\
\hline $\begin{array}{l}\text { Decreasing percent in seed yield } \\
\text { compared with } 100 \% \text { of F.C }(\%)\end{array}$ & $\mathbf{0}$ & -8.04 & -40.18 \\
\hline $\begin{array}{l}\text { Total water applied } \\
\left(\mathbf{m}^{3} / \text { feddan/season }\right)\end{array}$ & 1892.52 & 1514.02 & 1135.51 \\
\hline Total water application depth (mm) & 450.6 & 360.48 & 270.36 \\
\hline Water use efficiency, WUE, $\left(\mathrm{Kg} / \mathrm{m}^{3}\right)$ & 0.59 & 0.68 & 0.59 \\
\hline
\end{tabular}

Figure (3.6) illustrates the relationship between the three tested treatments from the point of view of water application depth, total cowpea seed yield and water use efficiency achieved in each treatment. The obtained results in table (3.4) and figure (3.6) showed that, decreasing total water application depth by $20 \%$ resulted in decreasing the obtained seed yield by $8.04 \%$, while decreasing by $40 \%$ led to decrease the seed yield by $40.18 \%$. The lower deficit percent of water application rate, the lower the water use efficiency. The results concluded that, the deficit percent might not be increased more than $20 \%$ in order to achieve higher water use efficiencies. 


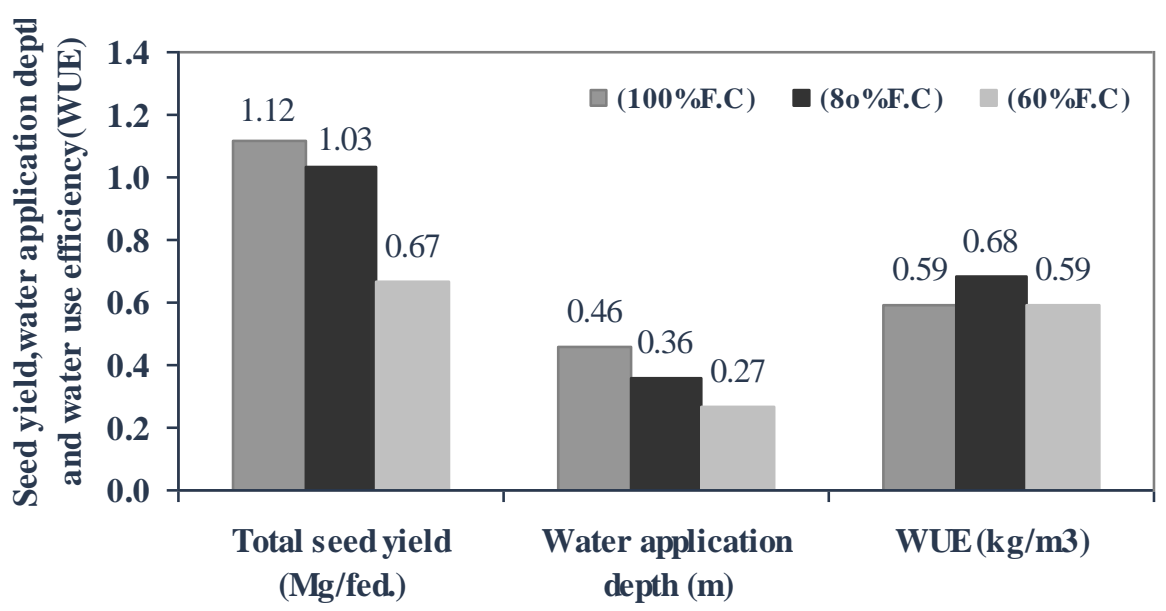

Fig. ( 3.6) : Total seed yield, total depth of water applied, and water use efficiency (WUE) for cowpea at different level of water deficit

\section{CONCLUSIONS}

Seed yield of cowpea is particularly sensitive to water deficit, where the highest seed yield (1.12 Mg/feddan) was observed with fully irrigation, while the lowest ( $0.67 \mathrm{Mg} /$ feddan) occurred when the water application is equal to $60 \%$ of soil moisture content at field capacity. This lowest value of seed yield was associated with low number of pods/plant (14.6 pods /plant) and small increase in number of seeds per pod (11.00 seeds/pod) and average seed weight (20.44 $\mathrm{g} / \mathrm{plant}$ ). Increasing the deficit percent of water application resulted in progressively lower water use efficiency. In case of application with $20 \%$ deficit (i.e. at $80 \%$ of soil moisture content at field capacity), water use efficiency was $0.68 \mathrm{~kg} / \mathrm{m}^{3}$ while, it decreased to $0.59 \mathrm{~kg} / \mathrm{m}^{3}$ as the deficit percent increased by $40 \%$ (i.e. at $60 \%$ of soil moisture content at field capacity). Water stress created differences in cumulative crop evapotranspiration (Etc) during the development and mid - season stages. The average seasonal crop coefficient $(\mathrm{Kc})$ was 0.646 , 0.516 , and 0.420 with fully irrigation, $80 \%$ and $60 \%$ of soil moisture content at field capacity respectively. Decreasing total water application depth by $20 \%$ resulted in decreasing the obtained seed yield by $8.04 \%$, while decreasing by $40 \%$ led to decrease the seed yield by $40.18 \%$.

\section{ACKNOWLEDGMENT}

The author thanks Engineer, Abd-Rabo Abd - El Aziem Abou-Kheira manager of the at Inshas Experimental Station, Institute of Irrigation Methods and Water 
Management Researches, National Water Research Center, Egypt for his helpful in introducing all the required facilities for this research.

\section{REFERENCES}

Abou-Kheira, A.A. 2009. Micromanagement of deficit - irrigated peanut with sprinkler irrigation. Agric. Water Manage, 9 (2009)1409 - 1420.

Andrade, C. L.T., Silva, A.A.G., Souza, I.R.P., Conceicao, M.A.F., 1993.Crop coefficients and irrigation coefficients for cowpea. EMPRAPA - CNPAI, Teresina, 6 pp. Comunicado tecnico, 9 (in Portuguese with abstract in English).

Detar, W.R., 2009. Crop coefficient and water use foe cowpea in the San Joaquin Valley of California.Agric.Water Manage., 96, 53 - 66.

Doorenbos, J. and A.H.Kassam., 1979. Yield response to water. FAO Irrigation and Drainage Paper 33, Rome, Italy, 193 pp

Farahani, H.Oweis, T. and G. zzi, 2008. Crop coefficient for drip -irrigated cotton in Mediterranean environment. Irrig. Sci. 26, 375 - 383.

Grema, A. K. and T. M. Hess., 1994. Water balance and water use of pearl millet - cowpea intercrops in north east Nigeria. Agric. Water Manage, 26 (1994) 169 - 185.

Hsiao, T.C., and E. Acevedo. 1974. Plant response to water deficits, water use efficiency, and drought resistance. Agric. Meteorology. 14: 59- 84.

Jensen, M. E., 1973.Consumptive use of water and irrigation water requirements. ASCE, P.215.

Maas, E.V. and J.A. Poss., 1989. Salt sensitivity of cowpea at various growth stages. Irrig. Sci., 10:313 - 320.

Nautiyal, P.C., and Y.C.Yoshi,2000. Deficit irrigation practice. FAO Water reports. No.22, Rome, Italy, 102 pp.

Ong, C.K., 1984. The influence of temperature and water deficits on the partitioning of dry matter in groundnut (Archis hypogaea L.). J.Exp.Bot.35, 746 - 755

Plaut, Z., and M.Ben - Hur, .2005. Irrigation management of peanut with a moving sprinkler system: Runoff, Yield, and Water use efficiency, Agro. J., 97, $1202-1209$. 
Richard, G., Lauis, S., Dirk, R., and S.Martin (2000). Crop evapotranspiration (guidelines for computing crop water requirements). ETc under soil water stress conditions, Chapter 8, FAO Irrigation and Drainage Paper 56, Rome, Italy, 161pp

Shouse, Peter, Samuel, desberg, W.A. Jury, and L.H. Stolzy., 1981. Water deficit effects on water potential, yield and water use of cowpeas. Agro. J, Vol. 73, March - April, 1981: 333 - 336.

Souza, M.S.M., Bizerra, F.M.L., and E.M.Teofilo, 2005.Crop coefficients for cowpea in the coastal region of the state of ceara (Brazil). Irrig. Botucatu 10 (3), 241 - 248 (in Portuguese with abstract in English).

Zesika, L. H. and A. E. Hall., 1982. Seed yields and water use cowpea (Vigna unguiculata, (L.)Walp) subjected to planned - water deficit irrigation. Irrig. Sci., 3: 237 - 245.

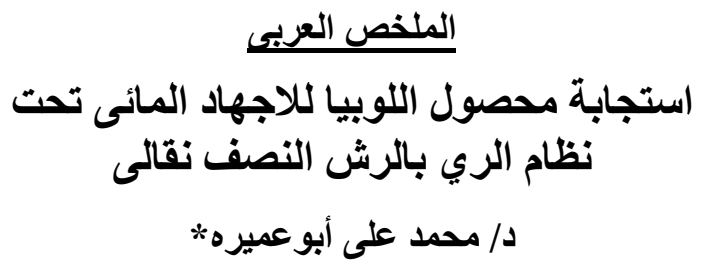

أجريت هذه الدر اسه بمحطة بحوث أنشاص التابعه لمعهد بحوث ادارة المعيزه المياه وطرث الري التابع

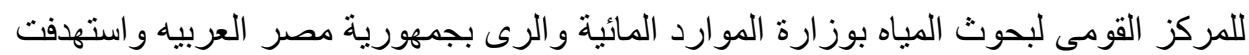
در اسة تأثير الأجهاد المائى على الانتاجية وقيمة معامل المحصول وكفاءة استخدام مياه الري لئي تحت نظام الرى بالرش النصف نقالى لمحصول اللوبيا (Vigna unguiculata, (L.)Walp)

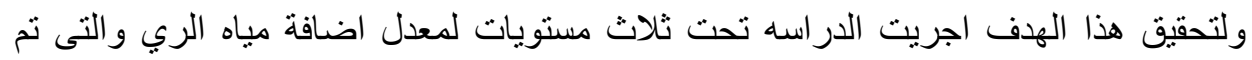

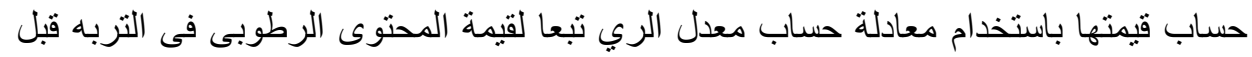

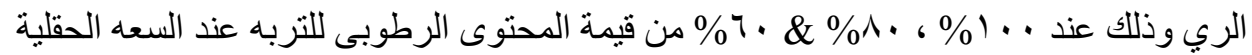

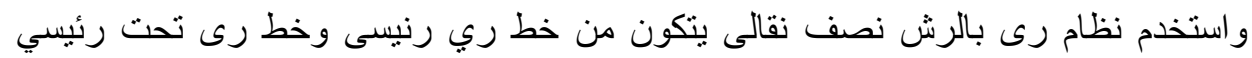
وثلاث خطوط رى فر عيه ثبتت عليها رشاشات من النوع (Rain Bird30TNT Sprinkler)

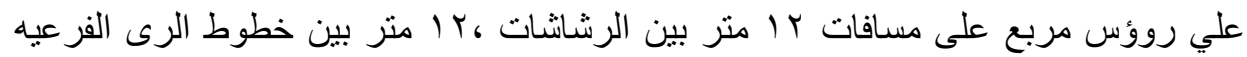

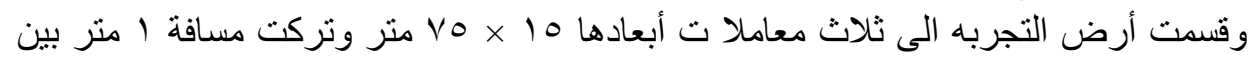
المعاملات لتفادى التداخل بين المعامله والأخرى ، و الرشاش المستخدم يعطى تصرف مقد مقداره 42.8لتر / دقيقه وتوصلت الدر اسة إلى النتائج الأتيه:

* استاذ مساعد بقسم الهندسه الزر اعيه ـ كلية الزر اعه جامعة المنوفيه 


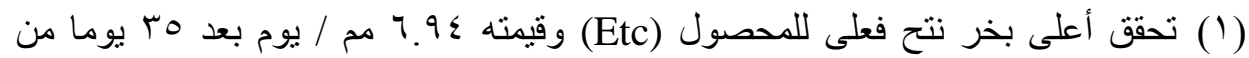

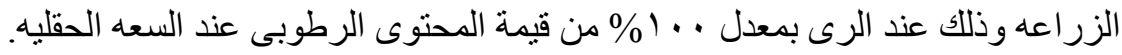

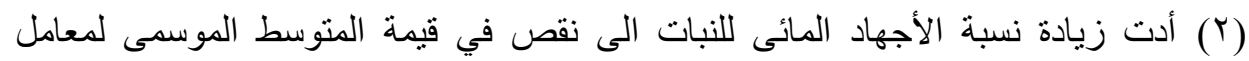

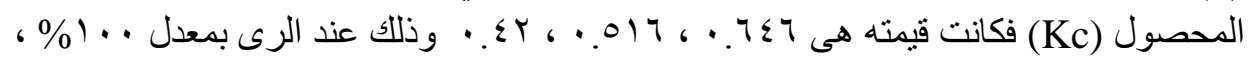

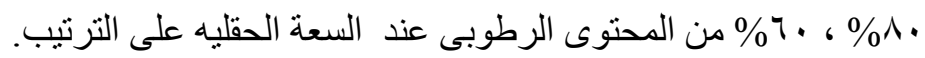

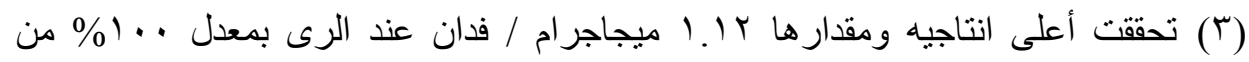

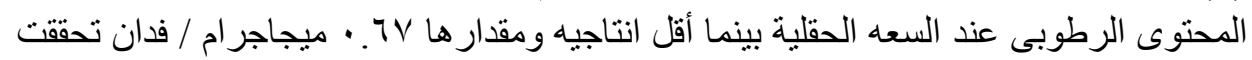

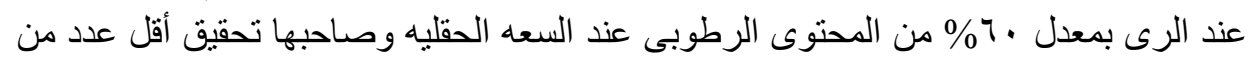

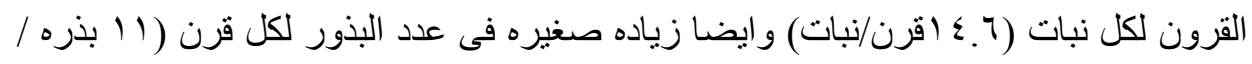

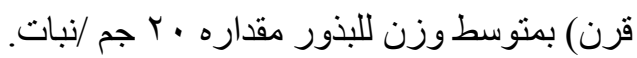

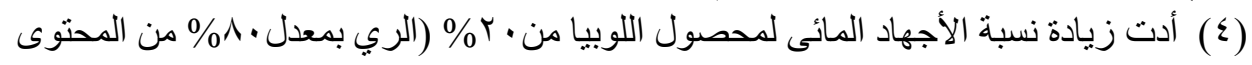

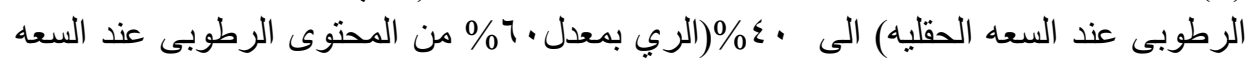

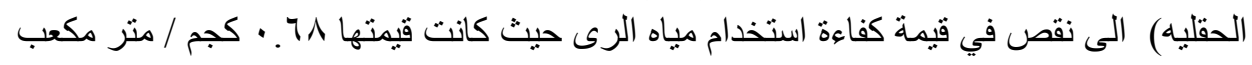

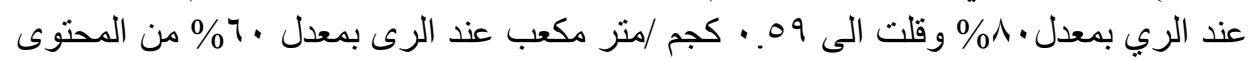
الرطوبى عند السعه الحقليه. 